\title{
Library Characteristics of Colleges Ranking High in Academic Excellence
}

BY ROBERT T. JORDAN

There is an extensive literature of persuasive writing arguing that the library is the heart of the college; so much so that this has sometimes become a cliché or platitude given lip service but not actual implementation by college faculty and administrators.

It would seem logical that librarians would be in the forefront in declaring the central importance of the library. However, an examination of the literature reveals that nonlibrarians have perhaps written as much as librarians on this subject, and sometimes with even more eloquence or forcefulness (perhaps librarians have been overly careful about offending the sensibilities of faculty or of appearing as extremists). For example, a scholar as eminent and respected as Henry Steele Commager has written as follows,

"Now that students can read for themselves, the English universities have turned more and more from lectures to tutoring or to self education ... but in the United States, which has the best library facilities in the world ... professors go on giving courses as blithely as if no printed books were available. One simple way, then, to meet the shortage of teaching talent, is to cut down on the lectures and therewith the number of professors that lectures call for. From the point of view of the student, the time spent going to lectures and preparing for course examinations can more profitably be spent in the library." 1

Despite the verbal recognition of the basic importance of the library, very little is actually known of the causal relationship existing between the quality or size of the library and the academic

1 "The Problem Isn't Bricks-It's Brains," New York Times Magazine, January 29, 1956, p. 11.

\author{
Mr. Jordan resides in McLean, Virginia.
}

quality of the school. It is commonly assumed that libraries of high quality are usually, if not always, associated with schools of high quality. Is it possible that these basically subjective impressions, albeit from knowledgeable and respected experts, can be proven? ${ }^{2}$ Probably not, in view of the multitude of complex variables and the virtual impossibility of any controlled experiments that would involve entire campuses.

Then how are we to know that libraries of high quality might not be a subsequent product of the quality of the school but not essential to that quality? Perhaps quality libraries and quality schools are the fortunate result of a combination of a particular milieu of faculty and student expectations, interests, and values.

\footnotetext{
2 There have been two recent indirect but impressive confirmations of the preeminent importance of the library for academic excellence. One is the study made by Harold B. Whiteman, Jr., dean of the freshman year, Yale University, quoted in an April 17, 1963 release from the National Book Committee: "Recently, we have administered to several successive entering classes in toto, the Library Orientation Test for Entering College Freshmen published by the Teachers College of Columbia University. Our purpose was to assist the staff of the library in making more effective its efforts to make accessible and understandable all of its resources, to fill in any gaps of information on the part of students when it came to the question of how to use a library. To our surprise, we discovered that the correlation between the results of this test and performance during the freshman year was extraordinarily high, higher than any other one single test."

The second indirect confirmation is Project Talent, by all odds the most authoritative and comprehensive study ever made of the American high school and the criteria that are related to quality. Of the many hundreds of possible criteria studied (from thousand-item questionnaires from one thousand high schools), four seemed to be of unique importance in association with scholastic excellence: teacher salaries, teacher experience, number of books in the school library, per-pupil ence, number of books in the school library, per-pupil
expenditure. This was true even when such factors as region, rural-urban-suburban status and socio-economic background of students were held constant. (Project Talent. A Survey and Follow-up Study of Educational Plans and Decisions in Relation to Aptitude Patterns: Studies of the American High School. Monograph No. 2. [Pittsburgh; University of Pittsburgh, 1962].)
} 
Apparently the hypothesis is not subject to rigorous proof. However if we can actually find that high-quality schools almost universally have highquality libraries and vice versa, there would certainly seem to be a persuasive suggestion that an operative causal relationship does actually exist. Such a correlation has not before been attempted, probably for lack of knowledge of what actually constitutes academic excellence, and which specific colleges could be considered to rank highest in academic excellence.

\section{Scoring of Colleges as to Academic EXCELLENCE}

There are no groups in America concerned with disseminating specific and critical information on the quality of colleges and universities comparable to the work of Consumer Reports, for example, in the field of consumer products, or of book reviews for books. The regional and national accrediting associations are specifically concerned about quality but not in any very precise or useful way, at least to the average citizen. Louis Joughin, staff associate in the American Association of University Professors, suggests:

"Fact and fiction with regard to the quality of the work done by the colleges and universities is a delicate subject. It is unnecessary to go over such familiar ground as inordinate emphasis upon athletics or the offering of masters degrees for studies not suited to intellectual inquiry. The weaknesses and malfunctions are known. What needs present emphasis is that the public is not informed about the facts. Admittedly, the choice of a means to display colleges and universities accurately and comprehensively is a large problem requiring full exploration. But one approach, at the very least, might be to establish more illuminating kinds and levels of accreditation; as things now stand, accreditation appears to be mainly a finding that an institution is not conspicuously defective in physical and staff resources. That is obviously not enough; there are far too many accredited institutions lacking other essential elements; or, if that pessimistic view is disputed, it is at least obvious that institutions which are miles apart in quality receive the same simple approval in terms of certification to the public." 3

In recent years there has been a pronounced upsurge of interest in quality in higher education. Many of the characteristics of academic excellence are now known with reasonable accuracy; the proof is the quality of the education absorbed by the student. Winslow Hatch, in a major statement on the hypotheses of quality "What Standards Do We Raise?; Criteria for Colleges" (Working Draft, January 9, 1962) states

1. There are criteria of excellence about which one can be explicit; which get at the "substance" as against the "forms" of higher education;

2. There is a pattern in these criteria as applicable to one institution as another;

3. These criteria are as important to the less well-endowed as to the most brilliant student; in a word, they are important to all students capable of profiting from a higher education.

Using a few commonly accepted criteria of academic excellence, I have developed an analysis of undergraduate colleges and universities related to the following:

\section{Faculty influence on students:}

a. Effectiveness in constructively and fundamentally changing values of the students, or in providing deeper insight into their present values. Weight of two. ${ }^{4}$

b. Peculiar potency of some colleges toward liberalism. Weight of two. ${ }^{4}$

2. Selected lists of best colleges made by others, emphasizing academic excellence:

a. Twelve top universities for graduate schools in the arts and sciences throughout the country. ${ }^{5}$

' Louis Joughin, "The Present Responsibility of Free Teachers," American Association of University Professors Bulletin, XLVII (June 1961), 151-58. - Philip E. Jacob, Changing Values in College (New York: Harper, 1957), pp. 99-116.

'Bernard Berelson, Graduate Education in the United States. (New York: Columbia University Press, 1960 ), p. 126. 
b. Forty-five nongraduate colleges tprivate $_{1}$ high on academic standards, selected by the American Conference of Academic Deans. Weight of two. ${ }^{6}$

c. Fifteen best liberal arts colleges in Illinois, Indiana, Iowa, Michigan, Minnesota, and Wisconsin. ${ }^{7}$

d. Forty best colleges. Weight of two. ${ }^{8}$

e. Fourteen top institutions. ${ }^{9}$

f. Graduate schools as ranked by graduate department chairman. Weight of two. ${ }^{10}$

g. Forty best colleges ranked by fifty professors and administrators. Weight of two. ${ }^{11}$

h. Four good private colleges. ${ }^{12}$

3. Proportion of graduates receiving doctoral degrees or other graduate distinctions:

a. Thirty highest in proportion of graduates who secured $\mathrm{PhD}$. in a natural science. ${ }^{13}$

b. Proportion of male graduates who achieved PhD.'s or fellowships-fiftyfive highest institutions. ${ }^{14}$

c. Proportion of female graduates who secured PhD.'s or fellowships-nineteen highest institutions. ${ }^{14}$

d. Sixteen highest in proportion of male graduates who achieved distinction among schools graduating eighty or fewer. ${ }^{14}$

e. Twenty highest in proportion of male graduates who secured $\mathrm{PhD}$. or fellowships in the humanities. ${ }^{14}$

f. Five highest among miscellaneous schools. ${ }^{14}$

-William E. Cadbury, “Outstanding Students in Liberal Arts Colleges," Liberal Education, XLVII (December 1961), 515-31.

? Chicago Tribune, February 3, 1961.

8 Paul H. Davis, "Changes Are Coming in the Col.

leges," The Journal of Higher Education, XXXIII (March 1962), 141-47.

Ford Foundation, Annual Report, 1961, 1962, 1963.

${ }^{10}$ Hayward Keniston, Graduate Study and Research

in the Arts and Sciences at the University of Pennsyl-

vania (Philadelphia: University of Pennsylvania Press, 1959 ).

${ }_{11}$ Chester Manly, "Greatest Schools in the Nation," Chicago Tribune, April 21, 1957.

${ }_{12}$ Martin Mayer, "Good Colleges That Are Not Crowded," Harper's, CCXVIII (February 1959), 44.49.

${ }^{13}$ Hubert Baker Goodrich, "The Origins of U.S. Scientists," Scientific American, CLXXXV (July 1951), 15.17. g. Proportion of male graduates who achieved distinction in social sciences -twenty highest institutions. ${ }^{14}$

h. Thirty highest in science doctorates. ${ }^{15}$

i. Thirty highest among college teachers. ${ }^{16}$

j. Thirteen highest women's colleges in proportion of graduates taking PhD.'s in arts, humanities, and social sciences. ${ }^{17}$

4. Faculty salaries. ${ }^{18}$

5. Willingness of the administration to take a strong position on matters affecting basic principles of academic freedom. Weight of two. ${ }^{19}$

6. Emphasis on the academic program as contrasted with social status, beauty contests, and quasi-professional athletic programs (e.g., schools without near-professional football, or fraternities). ${ }^{20}$

7. Receptivity to unique or experimental programs, or to the results of educational research, such as "year abroad" programs, work-study programs, elimination of departments or academic rank, cross-curricular experiments, etc. ${ }^{21}$

14 Robert H. Knapp and Joseph J. Greenbaum, The Younger American Scholar; His Collegiate Origins (Chicago: University of Chicago Press, 1953), pp. 16, $70,73,76,16,77,16$, respectively.

is William A. Manuel, The Baccalaureate Origins of Medical Students (Washington: Department of Health, Education, and Welfare, 1961).

16 Allan O. Pfnister, $A$ Report on the Baccalaureate Origins of College Faculties (Washington: Association of American Colleges, 1961).

it Sister Helen Sheehan, "The Catholic College and the Ph.D.," The Catholic Educational Review, LV (April 1957), 258-61.

13 "The Economic Status of the Profession, 1959-60: Annual Report by Committee Z," American Association of University Professors Bulletin, XLVI (June 1960), 162.

10 "Repealing the Disclaimer Affidavit," ibid. (March 1960), 55-61; "Protesting the Disclaimer Affidavit: the Association, the Colleges and the Universities,' the Association, the Coll
ibid. (June 1960), 205-06.

${ }^{20}$ As listed with the National Collegiate Athletic Association.

21 Institute of International Education, Programs for U.S. Undergraduates in Other Countries (New York: Institute of International Education, 1960); Institute of Research on Overseas Programs, International Programs of American Universities. (East Lansing, Mich. 1958); "College Programs-Unique or Experimental," Mademoirelle, XLVIII (January 1959); "The Editor's Bookshelf," Saturday Review, XLIII (November 19, 1960), 72; Seminar on the Economics of Higher Education, Harvard University, 1958-1959, Higher Educa. cation, in the United States, The Economic Problems, ed. by Seymour E. Harris (Cambridge: Harvard University Press, 1960); Elizabeth Paschal, Encouraging the Ercellent (New York: Fund for the Advancement of Education, 1960); U.S. Office of Education, New $\mathrm{Di}$ mensions in Higher Education, the Experimental Col. lege (Washington: Government Printing Office, 1960). 
8. Independent study programs, particularly those involving freshman or average students. ${ }^{22}$

9. Intellectual climate. ${ }^{23}$

10. Proportion of faculty in scholarly or professional organizations. Weight of two. ${ }^{24}$

11. De-emphasis or elimination of marks or grades (examination of 100 selected college catalogs reveal that six do this).

12. Elimination of faculty rank (examination of 100 selected college catalogs reveal that four do this).

13. Promotion of interdisciplinary atmosphere (examination of 100 selected college catalogs reveal that eight have eliminated departmental organization).

14. Average score of entering freshmen in scholastic aptitude. ${ }^{25}$

15. Ranking in effective scholarship money per student enrolled in proportion to total student expense. Weight of two. ${ }^{26}$

16. Strength of continuing education program. $^{27}$

The validity of each of the above criteria as an index to academic excellence may be confirmed by anyone. He may choose from personal knowledge ten schools that he would rank high in academic excellence and, using these criteria, compare them with another ten of average or poor quality. Another test of the validity of these criteria is an examination of the colleges actually ranked highest through use of these criteria. If

${ }^{22}$ Fund for the Advancement of Education, Better Utilization of College Teaching Resources, a Summary Report. A Report by the Committee on Utiliza. tion of College Teaching Resources. (New York: Fund for the Advancement of Education, 1959), p. 62 ; U.S. Office of Education, New Dimensions in Higher Education, No. 1. Independent Study (Washington: Government Printing Office, 1960); Robert H. Bonthius, The Independent Study Program in the United States (New York: Columbia University Press, 1957). ${ }_{23}$ George J. Stern, Intellectual Climate (Syracuse: Syracuse University. Press, 1962).

${ }^{24}$ Institutional Distribution (Washington: American Association of University Professors, Annual. Mimeo). 25 "Freshman Class: 1960," Life, XLIX (October 3, 1960). 95-101.

20 Theresa Birch Wilkins, Financial Aid for College Students; Undergraduate (Washington: U.S. Office of Education, 1957).

${ }^{27} A$ Ten Year Report, 1951-61 (New York: Fund for Adult Education), p. 95. these colleges are accepted as leaders in excellence, then it would appear valid to examine the relative ranking of the others as well. It is, of course, evident, however, that a deliberate selection of criteria and weightings can elevate any college or group of colleges to top ranking.

The above criteria do not discriminate schools on the basis of size, antiquity, wealth, prestige, or popularity. Rather they relate to total academic effectiveness as manifested in the creativity of its graduates; inclination toward speculative, critical, and independent thinking; responsible social and political action; receptivity to learning and to the new and different; capacity for independent study; objectivity; freedom from authoritarianism; intellectual curiosity; social independence and maturity; and appreciation of the arts. The above criteria apply only to liberal arts colleges; they are equally valuable in vocationally-oriented institutions. Neither are these criteria weighted to reflect the popular perversion of excellence to mean simply quantity (as against quality) of study, heavy assignments in traditional subjects, uncritical regurgitation of lectures in order to achieve high grades in examinations, or elimination of extracurricular activities.

The application of these criteria to the institutions named resulted in a numerical score for each, with high scores denoting academic excellence. Although the highest possible theoretical score for any college was 50 , in actuality no institution could, for technical reasons, have conceivably attained a score higher than 35. Ten institutions thus developed scores of 14 or more, the highest being Reed College with a score of 22. There were few surprises among the first twenty-five colleges; their quality is widely recognized. There is perhaps more interest in the next fifty or seventy-five. The scores, which are given in the appendix to this paper, were distributed as follows: 


\section{SCORE}

14 or over

10 through 13.

8 or 9

6 or 7

4 or 5

2 or 3

0 or 1

A great danger inherent in such an analysis is literal or uncritical acceptance. The listings obviously cannot be considered definitive or precise, in 1, 2, 3 order. They have value only in terms of order of magnitude, hence the use of seven groups. In a sense, the scores are still preliminary, as there are many dozens of criteria of excellence that can still be applied in order to build up a higher, and hence increasingly more significant, composite score (see Appendix C). No single criterion is all-significant. And also, any single criterion can be misinterpreted or misapplied, because of inaccuracies, vagaries, or gaps in reporting information. Such distortions and inaccuracies, however, become progressively less significant as more criteria are applied.

It is assumed that any institution in one group might actually deserve to be either in the next higher or the next lower group. Thus, any college with a score of 6 or 7 might actually deserve to be in the 8 or 9 group, or the 4 or 5 group.

One further qualification of the significance of the data must be made. In all instances an attempt has been made to secure the most recent data available; in some instances these data are current. In other instances, the supporting data are necessarily historical, from as many as ten or twenty years ago (as for example, the proportion of graduates eventually receiving doctoral degrees). Thus, a newly established college, or a college that is increasing its level of academic excellence at a rate higher than the average among all colleges, would be insufficiently recognized.
The general significance of the scores has been verified by the inspection of experts on the subject of academic excellence. However, the choice of criteria has been the author's (based largely on convenience of access to the supporting information), and in that sense it is subjective. The application of a different group of equally significant criteria (related to academic excellence) would doubtless result in a listing that would differ in a few details from that included in this report.

It should also be stressed that this study was designed deliberately to designate a group of approximately one hundred colleges among the several hundred that could be considered as excellent. This was done by use of a cutoff point for the twenty to forty top ranking colleges for each criterion. If the top one hundred to two hundred top ranking colleges for each criterion had been included, the list would undoubtedly have included several hundred colleges instead of 119.

\section{Correlation of Library Characteristics AND ACADEMIC EXCELLENCE}

The most comprehensive college library statistics are those of the Library Services Branch of the Office of Education which are published annually as Library Statistics of Colleges and Universities. The data collected in this publication were compared with the above excellence ranking of colleges in order to discover which data correlated most closely. In order to increase the homogeneity, publicly sponsored colleges were excluded, as were those colleges with fewer than five hundred students or with more than fifty graduate students. All colleges scoring 4 or more were included in one group (thirty-nine colleges total -the top 6 per cent of all colleges). A random selection of thirty-nine colleges was made from the group ranking 1 or 0 (the bottom 88 per cent of all colleges). Correlation between criteria listed be- 
low and academic excellence of the institution:

High correlation

Volumes in library

Volumes in library for each undergraduate student

Per student salary expenditure by the library

Moderate correlation

Age of the school

Per student operating expenditure by the library

Number of periodical subscriptions in the library

Low correlation

Volumes acquired per year by the library

Ratio of library expenditure to total expenditure

Two specific conclusions from this study are that in high quality colleges with more than five hundred students and less than fifty graduate students a minimum of approximately fifty books per student and approximately fifty thousand books in the collection is required. The difference between the high ranking schools and all other schools is decisive - on the order of two to one-as can be seen from Table 1 .

Using Shephard's method of unlike signs, the correlation coefficient is approximately .97 , which means that there is practically no possibility that the difference between the two groups could be due to chance.
If it would be possible to identify the bottom 6 per cent instead of the bottom 88 per cent, the contrast between the two groups would doubtless be of the magnitude of four or five to one.

Total salaries paid to library staff are also closely associated with academic excellence, as can be seen from Table 1 . However, the dollar amounts are based on reports from 1958-59. Extrapolating to present salary levels, it is clear that a minimum of from $\$ 25$ to $\$ 30$ is required in library salaries for each student enrolled.

Although there is not such a high degree of correlation, it would appear that a minimum of three hundred and fifty periodical subscriptions is required in a college ranking high in academic excellence and a minimum library expenditure per student of $\$ 50$. Even though less precise, it would appear that at least two thousand volumes a year and an expenditure for the library of at least 3.5 per cent of the total school expenditure is required for colleges ranking high in academic excellence.

In the compilation of this study, distinctions were made between colleges with more than one thousand students, men's, women's, and co-educational colleges, and colleges with scores of more than seven on the ranking scale. There were no very precise conclusions from these further comparisons, except that the larger schools had larger libraries, and that the schools ranking above seven

TABLE 1

\begin{tabular}{|c|c|c|c|c|c|c|}
\hline & \multicolumn{2}{|c|}{ VOLUMES IN LIBRARY } & \multicolumn{2}{|c|}{$\begin{array}{cl}\text { VOLUMES IN } \\
\text { LIBRARY FOR EACH } \\
\text { UNDERGRADUATE STUDENT }\end{array}$} & \multicolumn{2}{|c|}{$\begin{array}{l}\text { PER STUDENT } \\
\text { SALARY EXPENDITURE } \\
\text { BY THE LIBRARY }\end{array}$} \\
\hline & $\begin{array}{l}\text { Colleges } \\
\text { ranking } \\
4 \text { or over } \\
\text { (top } 6 \% \text { ) }\end{array}$ & $\begin{array}{c}\text { Colleges } \\
\text { ranking } \\
1 \text { or } 0 \\
\text { (bottom } 88 \% \text { ) }\end{array}$ & $\begin{array}{l}\text { Colleges } \\
\text { ranking } \\
4 \text { or over } \\
\text { (top } 6 \% \text { ) }\end{array}$ & $\begin{array}{c}\text { Colleges } \\
\text { ranking } \\
1 \text { or } 0 \\
\text { (bottom } 88 \% \text { ) }\end{array}$ & $\begin{array}{l}\text { Colleges } \\
\text { ranking } \\
4 \text { or over } \\
\text { (top } 6 \% \text { ) }\end{array}$ & $\begin{array}{c}\text { Colleges } \\
\text { ranking } \\
1 \text { or } 0 \\
\text { (bottom } 88 \% \text { ) }\end{array}$ \\
\hline $\begin{array}{l}\text { Highest library } \\
\text { 75th percentile } \\
\text { Median } \\
\text { 25th percentile } \\
\text { Lowest library }\end{array}$ & $\begin{array}{r}328,000 \\
165,000 \\
102,000 \\
76,000 \\
44,000\end{array}$ & $\begin{array}{r}279,000 \\
60,000 \\
50,000 \\
37,000 \\
28,000\end{array}$ & $\begin{array}{r}366 \\
185 \\
124 \\
94 \\
47\end{array}$ & $\begin{array}{r}187 \\
77 \\
60 \\
48 \\
14\end{array}$ & $\begin{array}{l}\$ 110.00 \\
\$ 46.00 \\
\$ 35.00 \\
\$ 25.00 \\
\$ 20.00\end{array}$ & $\begin{array}{l}\$ 40.00 \\
\$ 25.00 \\
\$ 20.00 \\
\$ 14.00 \\
\$ 8.00\end{array}$ \\
\hline
\end{tabular}


tended to have larger libraries than those ranking from three to six. One interesting sidelight is the conclusion that a private co-educational school, with less than one thousand students, with a library of more than sixty thousand volumes, is almost certain to have a high ranking in academic excellence.

There are various possibilities for a "common sense" inspection of the conclusion that a minimum of $50,000 \mathrm{vol}$ umes are required in a college ranking high in academic quality. For example, two hundred and fifty courses constitute a moderate number for a typical college (ten courses in each of twenty-five subject fields). If the library has an average of one hundred and fifty books to support each course, certainly a modest amount, plus twelve thousand and five hundred books not directly related to any specific course, the total would be fifty thousand volumes.

It is fairly conclusive that fifty thousand volumes are required in a good college library. However, the reverse is not necessarily true, that fifty thousand volumes in a library will insure either a good staff or a high level of academic excellence. Obviously the quality of the library staff and the quality of the instructional staff must to some degree match the quality of the library collection. It is conceivable that an administration of a poor quality school might buy a random assortment of old books, by the ton, simply to claim that its library contained fifty thousand volumes. Nevertheless there is probably a large area for improvement in most libraries. Martin Mayer, who spent three years visiting schools in Europe and the United States in preparation for his book The Schools, states,

“... the library should have one very special attraction: it is the only place in education where excellence can be assured by the expenditure of money. Given a librarian who knows her business and who reads, the quality of a library is a simple function of the cash spent.... In the United States, perhaps the easiest immediately available improvement would be to take 10 per cent or so of the money now devoted to educational administration and put [it $_{]}$into library books." 28

28 "Next to Teachers, the Library Is the Heart of Any School," Washington Daily News, June 7, 1961, p. 50 .

\section{Appendix}

Scores for individual undergraduate colleges (the number of volumes per student is indicated for all colleges with more than five hundred students and fewer than fifty graduate students).

Score of 14 through 22:

Amherst

Antioch

Carleton 153

Chicago

Grinnell

Harvard (and Radcliffe)

Haverford

Oberlin

Reed

Saint John's (Md.) .

Sarah Lawrence
Swarthmore 261

Wesleyan Univ.

Score of 10 through 13:

Bennington

Bryn Mawr

Columbia .

Dartmouth

Goddard

Goucher

Hamilton .

Mount Holyoke .

Princeton .

Vassar .

Yale

Score of 8 or 9 :

Beloit .

Bowdoin 
CIT

* Claremont (Assoc. Colleges)

Cornell (N.Y.)

Elmira

Kalamazoo

Mills

Park

Smith

Williams

Score of 6 or 7 :

Allegheny

Austin

Bard

Bates

Berea

Brandeis

Brown

California (Berkeley)

California (Los Angeles)

Cornell (Iowa)

Drew

Earlham

Hollins

Johns Hopkins

Kenyon

Knox

Macalester

MacMurray

Michigan

Monmouth (Ill.)

South, Univ. of

Southwestern (Tenn.)

Stanford

Wabash

Wells

Wilson (Pa.)

Wisconsin

Wooster

Score of 4 or 5 :

Agnes Scott

Barnard

Bethel (Kan.)

Birmingham-Southern

Blackburn

Brooklyn

Chatham

Clark (Mass.)

Coe

Colby
Colorado College

Cooper Union

Davidson . . . . . . . . 90

94 Dickinson . . . . . . . 95

116 DePauw . . . . . . . . 66

195 Duke

Florida Presbyterian

Franklin \& Marshall

230 Greenville

Heidelburg . . . . . . . 65

Hiram . . . . . . . . 111

119 Hood . . . . . . . 85

70 Illinois

Lafayette

125 Lake Erie

Lawrence

Lewis \& Clark

MIT

Marlboro

95 Minnesota

Notre Dame (Md.) . . . . . 90

110 Occidental

98 Oklahoma City Univ. . . . 26

291 Pennsylvania State

110 Pennsylvania

47 Principia

86 Queens

Randolph-Macon Women's College 130

108 Rice

144 Ripon.

120 Rochester

Saint Lawrence Univ. . . . . 118

155 Saint Mary's (Ind.) . . . . . 55

Saint Olaf . . . . . . 81

138 Shimer

Sweet Briar . . $\quad 180$

111 Trinity (Conn.)

Trinity (Wash., D.C.) . . . 95

Union (N.Y.) . . . . . 180

121

Univ. of the Pacific

60 Wagner

60 Yankton

Yeshiva

(Note that the 119 colleges listed are ap110 proximately 5 per cent of all colleges and universities in the United States,

75 hence all of the 119 can be considered to 190 belong to an "excellent" category.) 